\title{
The influence of the distribution of household and childrearing tasks between men and women on childbearing intentions in Austria
}

\author{
Isabella Buber-Ennser*
}

\begin{abstract}
It is the purpose of this paper to look at the extent to which the division of household work and childrearing tasks influence a couple's plans of further childbearing. We concentrate on women with one child, looking at the question whether women whose partners share the domestic responsibilities wish to have a second child more often than women with partners who do not help out. The data used in this study are drawn from the Austrian Fertility and Family Survey 1995/96 (FFS) which covered biographies of partnerships and childbearing, detailed information on the division of household chores and childcare duties between the two sexes as well as the desire for a (nother) child. We modelled the desire for a second child using a probit model. The major findings of the paper are that sharing childcare duties among couples is a driving force behind the plans for further childbearing, whereas the division of (traditionally feminine) household tasks between men and women has no explanatory power.
\end{abstract}

\section{Introduction}

Like many other European countries, Austria has been witnessing declining birth rates over the last decades. To a large extent, the currently low levels of fertility are caused by the tendency of couples to stop childbearing after the birth of the second child (Hoem et al. 1999) and cohort parity progression ratios for Austria suggest that much of the fertility decline in our country has been concentrated at parities two and above (Hanika 1996). Therefore nowadays fewer and fewer couples have more than two children, and one might speculate that in the future an increasing number of couples may decide to have only one offspring. The purpose of this study is therefore to examine the childbearing plans of women with one child.

This paper aims to make a contribution to research on childbearing intentions among women, focusing on a gender perspective. A central issue in gender theory is work, inequalities in both paid and unpaid work having stimulated sociological and economic re-

* This analysis has benefited greatly from discussions with my Ph.D. supervisor Jan M. Hoem. Moreover, comments of unnamed reviewers have also helped to improve the paper. I thank the Max Planck Institute for Demographic Research for providing access to its excellent library and computer facilities where part of this work was carried out. An extended version of this paper was published as a Max Planck Working Paper (Buber 2002). 
search. Apart from studies on the distribution of paid work and housework, some researchers have also focused on the consequences that the distribution of tasks between women and men may have. There is some evidence that gender inequality in the family affects marital stability and the well-being of women (Blair 1993, Glass and Fujimoto 1994), but it might also influence other areas of family life that have been neglected so far. It is the aim of this paper to look at the question to which extent the division of domestic duties influences the desire for further children.

\section{Theoretical aspects of the division of household labor}

Housework mostly refers to unpaid work performed in order to maintain a family and/ or a home. Research on the division of household labor has generated a considerable number of studies and mainly focuses on (1) the measurement of housework, (2) historical developments, (3) explanations for the division of household labor, and (4) consequences of the division of household labor (Shelton and John 1996).

Explanations for the division of household labor mainly focus on three approaches: (1) gender theory, (2) the theory of relative resources and power, and (3) the theory of time availability or time constraints. Empirical research on this subject is dominated by studies that include a combination of these theories (e.g. Presser 1994).

Let us give a short description of the central ideas of these three approaches. Gender theory focuses upon the extent to which (1) specific behavior patterns and roles are given gendered meanings, (2) labor is divided to express gender difference symbolically, and (3) diverse social structures incorporate gender values and convey gender advantages (Ferree 1990, p. 868). The "social construction of gender" approach assumes that early socialization and intergenerational influences are important for the gendered division of housework (Cunningham 2001). Housework is perceived to be more than the invisible and unpaid labor that makes waged work possible; it is seen as constituting a set of culturally and historically specific tasks that convey social meanings of masculinity and femininity (Berk 1985). This implies that housework produces household goods and services and also gender itself (Hartmann 1981). The proposition that gender is continuously being constructed and used to further a variety of individual and group goals is central to what West and Zimmermann (1987) called "doing gender" (Ferree 1990, p. 869).

According to the "relative resources" explanation, the individual commanding the larger part of resources (education, earnings, occupational prestige, age) uses those resources to negotiate his/her way out of housework. Husbands and wives with more relative resources (higher income, education) would thus, all other things being equal, spend less time on domestic activities. For the theory of relative resources and power, see Hiller 1984.

The "time constraint" approach suggests that men and women participate in household and childcare duties to the extent that there are demands on them to do so and to the extent that they have time available (Presser 1994). Employment and/or hours worked and the presence or number of children in the household are the most commonly used indicators for time constraints. According to the time-constraint theory, persons in the labor market - and in particular those who work more hours than the norm - have less time at their hands for household tasks, especially when both spouses are employed. 
Studies on the impact of the division of household labor mainly concentrate on its consequences for (1) marital satisfaction or marital conflicts (e.g. Blair 1993, Dillaway and Broman 2001), and (2) health and psychological well-being (e.g. Baruch and Barnett 1986, Glass and Fujimoto 1994).

Turning our attention to the perceived fairness of the division of work and/or housework between men and women, a starting point would be the general observation that meanwhile women and men no longer divide the task of breadwinning strictly according to gender. Nevertheless, although women increasingly contribute to the family income, the division of unpaid housework among partners still remains more or less unchanged. Despite clear evidence that gender inequalities exist in the division of household labor between the two sexes, most men and women regard this division as fair (Berk 1985, Blair 1993, Blair and Johnson 1992, DeMaris and Longmore 1996). This phenomenon has stimulated various studies on the perceived fairness of the division of household tasks, with theoretical explanations being based on (1) ideology (gender role), (2) power, and (3) equity (DeMaris and Longmore 1996, Blair and Johnson 1992, Sanchez 1994).

In an attempt to explain the perceived fairness of the division of household and childcare tasks among spouses, the feminist approach suggests that the inequitable division of household labor between the two sexes is accepted as long as societal norms define most household tasks as "feminine" activities. Other key determinants of perceived fairness in household labor are women's alternatives to remaining in the relationship - briefly, women's power issues. Research pertaining to equity assumes that "to the extent that partners perceive husbands as compensating for a low input in household labor with greater input in other important domains of the relationship, such as paid work or childcare, individuals will feel that women's greater contributions to housework are justified" (DeMaris and Longmore 1996, p. 1044). Research has found mixed results for the impact of ideology, some support for the power hypothesis but only little support for the equity theory (DeMaris and Longmore 1996).

\section{Time use and the division of household work in Austria}

We now give a brief description of time use in Austria. "Time use" refers to the hours and minutes a person spends on paid work, education, household work, childcare, leisure, sleep, and private matters. In Austria, two official surveys on time use of the population have been carried out up to now (1981 and 1992). We are using the data collected in 1992 and concentrate on their time-use patterns found for married or cohabiting couples having at least one child under 15 years.

Women do the lion's share of family work; they spend from six up to nearly nine hours per day on household work; their male partners put in two hours on average (Table 1). On weekdays, this segregation is even more distinct (Monday to Friday: women: 6 to 91/2 hours, men: $1 \frac{1 / 2}{2}$ to $1^{3 / 4}$ hours; see Table 1 ). As expected, although employed women spend less time on household work than those who are not employed, they are still bearing the main burden of household work. Women who are in full-time employment spend $5^{3 / 4}$ hours a day on household work, women who work part-time $6^{1 / 4}$ hours, and non-employed women $83 / 4$ hours. 
The number of hours a woman spends in full or part-time employment has almost no effect on her partner's participation in household work. This finding supports cross-national studies which reveal that the nature of women's labor market employment has no significant effects on the involvement of their partners in domestic labor (Brines 1994). Austrian men whose wives are employed full-time participate only slightly more in household work than those with wives on part-time employment or none at all (about 15 minutes more per day). The hours mentioned here refer to time spent on "traditional" household chores such as cooking, washing and cleaning, but also on other activities, such as handicraft, childcare, and care of the needy (mostly elderly family members).

\section{Government policy and public discourse}

Contemporary government policy as well as the public discourse are "likely to influence gender relations at both the family and the societal level either by promoting or by slowing down changes in traditional gender roles" (Oláh 2001b, p. 31). For Austria, we would like to mention in this context the introduction of parental leave in 1991, the "halbehalbe" campaign and the women's referendum, both held in 1997, and use these as examples to illustrate that contemporary government policy and public discourse did in fact encourage the active participation of men in parenting and household work.

In Austria, mothers have been eligible for maternity leave (with a flat-rate benefit) since 1961 and fathers became eligible as well in 1991. The extension of maternal leave to parental leave can be seen as a step towards greater gender equity supporting a closer involvement of fathers in childrearing. Nevertheless, only a few Austrian fathers have used the opportunity to take parental leave. When it was introduced, only 0.6 percent among parents on parental leave were fathers, and in 1998 the percentage was still negligibly low, with a share of 1.6 percent (Tazi-Preve et al. 1999).

Very often economic reasons are given for the low percentage of Austrian fathers who take parental leave. The fact that parental leave benefits are relatively low does not encourage fathers to engage in active parenting. The earnings of men are generally higher than those of women and thus the man's leave-taking would usually reduce the family income to a larger extent than if the woman stays at home. Further reasons are the possible social stigmatization attached to fathers taking parental leave as well as little sympathy for these fathers among employers.

In 1997, the former Federal Ministry for Women's Affairs organized a media campaign called "halbe-halbe" with the intention to open a public debate on the distribution of labor market employment, income, household work, and parenting between men and women. Halbe-halbe translates simply as "fifty-fifty", meaning that women and men should share work and household duties equally. Characteristically, the ensuing public discussion on a more equal distribution of housework and caring duties died out rather quickly.

The Austrian "Frauen-Volksbegehren" (petition for a referendum on women's affairs) in 1997 generated further public debate. The main demand was to embed equal rights for women and men in the Austrian Federal Constitution and to gradually remove discrimination of women. The petition included the demand for eleven legal provisions, including a minimum wage, social benefits also for those who work only a few hours a week and concrete provisions to improve the compatibility of paid work and childrearing both for men and women (Frauen-Volksbegehren 1997). 


\section{Our hypotheses}

Aspects of gender theory and gender attitudes are increasingly being incorporated in demography and the social sciences and have also been included in a few studies on fertility. In an analysis of couples' births in the United States, Thomson (1997) included gender attitudes and found a significant effect of wives' gender attitudes on birth rates. Women with more egalitarian gender attitudes were more likely to have a child and she speculated that "these women, compared with gender-traditional women, anticipated greater participation by their husband in childcare and childrearing" (Thomson 1997, p. 348). For Sweden and Hungary, Oláh (2001a) recently found higher second-birth intensities for couples who share family responsibilities than for couples with traditional gender role behavior. Since the Austrian FFS distinguishes between household tasks and childcare duties, we are able to enlarge Oláh's analytical framework and to carry out a more sensitive analysis.

In this paper we hypothesize that the extent of gender equality in a relationship influences fertility in Austria. We have two main hypotheses which we want to test, namely that both (1) the division of (unpaid) domestic work and (2) a woman's own evaluation concerning the division of domestic responsibilities influence her further childbearing plans. In a third hypothesis, we assume that a woman's personal evaluation of the distribution of household labor is more relevant than the actual distribution of tasks.

Scholars have pointed out that the uneven balance of power between women and men in the family influences the reproductive decision-making and behavior of individuals (Hartmann 1981). The presence of a partner who is involved to a comparably high extent in domestic work and childcare duties might more easily encourage a woman to have a further child. Aside from aspects of gender theory, we refer to the concept of "new home economics" to understand the relation between the distribution of household work among couples and women's further childbearing plans. An attempt to explain the interdependencies between economic factors and fertility was made by Gary Becker and his "new home economics" in general. Becker's intention is to analyze marriage, birth and other nonmaterial behavior with the tools and framework developed for material behavior by postulating that the household has a utility function which has to be maximized. In a first step the utility function depends on the quantity of children, the expenditures per child (called the quality of children), and the quantities of other commodities. He states that children are "self-produced by each family, using market goods and services and the own time of parents, especially of mothers" and deduces that the demand for children depends on the relative price of children and full income (Becker 1981, p. 96). From the "new home economics" perspective we might assume that the man's help in running the household decreases the woman's opportunity costs of having a(nother) child. In other words, we hypothesize that a woman is more likely to want a(nother) child when the partner makes a valuable contribution to household and childcare tasks, compared to a woman whose partner helps only a little or not at all.

Aside from the quantitative aspect of household task sharing there is also a qualitative one which takes into account women's evaluation of the distribution of housework. Therefore, we assume in our second hypothesis the positive evaluation of the division of household work to be associated with an increased wish for a further child.

Several studies on the division of household labor and consequences for marital satisfaction found that perceived fairness is a better predictor of a lack of marital conflict than the actual extent of inequality in the division of labor (Blair 1993, Perry-Jenkins and Folk 1994). For the purpose of our paper, we hypothesize that women's evaluation of the distri- 
bution of domestic work is more relevant for their childbearing plans the actual amount or percentage of time their partners spend on doing housework. It is not clear whether it is the husband's amount of time spent or his degree of involvement in household work that affects the wife's childbearing plans, or whether it is the wife's satisfaction with the division of household work and childcare tasks that is the operational factor.

Our analysis also includes factors that are not of main interest to us but that have been found to greatly influence childbearing in previous studies. We use them as control factors to avoid confounding. Following Oláh (2001a), we control for individual characteristics, maturity at parenthood, "union-specific characteristics", the characteristics of the partner, the age of the first child, and family orientation, as described in our Appendix.

\section{Data and method}

The empirical analysis of this study is based on data extracted from the Austrian Fertility and Family Survey (FFS), which was conducted between December 1995 and May 1996 (Doblhammer et al. 1997). The survey gives a rich set of data on retrospective histories of partnerships, childbearing, education, and occupational activities. It also includes detailed information on the division of household work and childrearing tasks between the sexes, as well as on the desire for (further) children.

In the survey, persons who are living together with a partner were asked in what way they organize their household work. Before listing the tasks included in our analysis, a preliminary distinction between female and male household tasks has to be given. Household labor remains highly segregated by sex, as there are differences in the nature of family tasks that women and men typically accomplish. This leads to the distinction between "feminine" or "female" household work such as cooking, laundry, or housecleaning, traditionally thought of as "women's work", and "masculine" or "male" tasks such as garden work or car maintenance (Baruch and Barnett 1986). In order to study the effects of gendered behavior, we included five household tasks in our analysis, namely (1) cooking, (2) vacuuming and tidying up, (3) grocery shopping, (4) washing the dishes, and (5) doing the laundry and ironing. These items represent the feminine tasks at home and are everyday activities. We added up the number of household tasks performed mainly by the woman, her partner, both, or others.

Respondents with at least one child were interviewed about the degree to which childcare tasks in their household are distributed between the two sexes. For childrearing, we included four duties, namely (1) preparing the child's food, feeding a small child, (2) dressing the child, (3) looking after the child when ill, and (4) playing with the child and having other activities that involve the child. Again, we summed up the number of chores carried out primarily by the woman, her partner, both, or others. ${ }^{1}$

In order to find out about the perceived fairness of household work distribution, respondents were asked - for household tasks and childcare duties separately - how they evaluated the distribution of work, using a 5-point Likert-type scale ranging from "very just" to "very unjust".

1 For further details on the information included in the dataset and the coding of the household chores, childcare tasks and the desire for a further child, see Buber (2002). 
For the purpose of the present study, we selected women with one child, who were living with a partner at the time of the interview. ${ }^{2}$ We took steps to make the sample as homogeneous as possible and confined ourselves to a sample of 364 Austrian women born between 1941 and 1976 who had one child and were sharing household duties with a partner at the time of the interview.

The analysis is based on a probit model. It can be described as a nonlinear regression model with a binary dependent variable $Y$. The variable $Y$ is assumed to depend on $k$ observable variables $X_{1}, \ldots, X_{k}$ and on a disturbance term $u$. The question of interest is the probability that $Y$ equals 1 , mathematically $P\left(Y=1 \mid X_{1}, \ldots, X_{k}\right)=\Phi\left(\sum_{k} \beta_{k} X_{k}\right)$, where $\Phi$ denotes the standard normal distribution function. In our study the dependent variable $Y$ takes the value 1 if a woman wants to have a second child, and it takes the value 0 if she does not. The standard probit model assumes a normally distributed random term $u$, i.e. $u \sim \mathrm{N}(0,1)$. (For further details on probit models see Aldrich and Nelson, 1986). The remaining unknowns are the parameters $\left\{\beta_{k}\right\}$ which represent the effects of the variables included in the model. We apply the software aML (Lillard and Panis 2000) for their estimation.

\section{Results}

As mentioned in the previous chapter, the Austrian FFS includes information not only on household work in general, but also on the type of work by distinguishing between household chores and childcare duties. Turning to our data extracted from the Austrian FFS, we see that the distribution of feminine household chores is consistent with the findings of previous research in the sense that women indeed do the major part of household labor. Most of the household chores in our sample are performed primarily by the woman, though some chores are carried out by both partners Table 2). Childcare tasks are shared to a greater extent by both partners: eight out of ten women report that they share with their partner at least one of the four childcare tasks looked at in our sample, compared to six out of ten when asked about household chores. Although women carry the main burden of family work, only few feel that the distribution of domestic responsibilities is unjust (Table 2).

Among the women in our sample (parity 1 and living with a partner at the time of the interview), 33 percent wanted to have another child within the next two years, 60 percent would like a second child but had not made up their mind yet. Therefore, only one third had a rather "concrete" wish for a second child, whereas nearly twice as many wanted to have a second child at an undecided point in time; this indicates the likelihood of rather low birth intentions in the near future. We have estimated two models with different time horizons, namely the desire for a second child (1) within the next two years, and (2) at a yet undecided point in time. The time span for which a second child is planned is rather unimportant for our results. In general, the effects of our explanatory variables on the

2 We did not include childless women because many of them were not living in a union at the time of the interview. Therefore, it is not possible to analyze the effect of the distribution of household tasks, and - of course - of childcare duties. Including only those childless women who were living together with a partner at the time of the interview would strongly bias the sample. 
desire for a second child within the next two years and for a second child at a yet undecided point in time are similar and more pronounced in the model on the desire for a second child at an undecided point in time.

Table 3 gives the estimated effects, the ratio of intention of each category versus the reference category is computed from the estimated value of the coefficient $\beta_{i}$ by the transformation $e^{\beta i}$. The reference group is the level indicated with an effect of 1 . An estimate larger than 1.00 means a greater likelihood of intending to have a second child.

Our data support our first hypothesis for childcare duties but not for household tasks. Although we find evidence that the contribution men make to household work does increase the desire of women for a second child, our effects are only significant to a certain extent and therefore have only a low predictive value (Table 3 ). ${ }^{3}$

The analysis presented in Table 3 shows significant effects of men's active role in childcare. Mothers with one child whose partners are responsible for at least one out of four specific childcare tasks have a much higher desire for a second child than those whose partners are responsible for none of these tasks. Aside from the significance, the magnitude of the effect is very marked (4.68 and 2.97). Furthermore, sharing childcare tasks makes a significant contribution to explaining childbearing desire. The more tasks both partners share, the higher is the woman's desire for a second child: sharing two childcare tasks with the partner increases the probability of further childbearing intentions by a factor of 2 , sharing three tasks by a factor of 3 . (The reference group are women who share one childcare task with their partner. $)^{4}$

Our findings corroborate Oláh's (2001a) recent study on Sweden and Hungary in which she shows that there are higher second-birth intensities among couples who share family responsibilities. The fertility costs of women are reduced in relationships in which men participate in housework and childrearing, most likely since compatibility of employment and parenthood is easier for these women as their partners share the responsibility of caretaking for the child (Oláh 2001a). The indicator for gender relations used for Sweden is the engagement of men in active parenting, measured by the question whether or not he took parental leave for the first child. For Hungary, she combines information on the division of household chores and childcare duties into one variable. In this paper, we enlarged her analytical framework by distinguishing between household labor and childrearing, and by including the women's satisfaction with the distribution of housework. This allows for a more sensitive analysis and shows that the distinction between household tasks and childcare duties is important when studying domestic duties.

Our findings on women's evaluation of the distribution of household work and childcare duties both are rather insignificant overall. We therefore have to reject our second hypothesis. Interestingly, women who evaluate the distribution of household work or of childcare duties as unjust more often wish to have a second child than those who feel that the distribution is just.

In our third hypothesis we assumed that a woman's subjective assessment of the division of childcare duties might be more important than the actual division of the specific tasks. This conclusion does not hold up in the light of our results, as we clearly see that the additional explanatory power of women's evaluation of the distribution of tasks is rather small.

3 For more details see Buber (2002), Appendix A.5.

4 The startlingly high coefficient (11.77 and 34.80) for women who share with their partner all four childcare tasks considered might be explained by the relatively small size of this group (8 per cent, see Table 2 ). 


\section{Discussion}

In an attempt to enhance our understanding of childbearing plans we have included gender aspects in our analytical framework. As a measure of gender equality in a relationship we used the information on housework division, the sharing of childcare tasks, and the comparison women make when it comes to the division of family work at the time of the interview. Our results show that the division of childcare duties is a driving force behind the childbearing plans of women, whereas the distribution of "feminine" household tasks among the partners has no explanatory power (Table 3 ).

The hypothesis that the active contribution of men in childrearing increases the desire of women to have a further child is confirmed by our analysis. Egalitarian partners who make relatively large contributions to everyday childcare tasks facilitate the decision of women to have a second child. Certainly, the participation of men in childcare duties alleviates women's burden of childrearing. The daily childcare duties looked at in our analysis, which include feeding, dressing, caring, and time spent with the child, strengthen the bond between child and parent (father) and increase parental competence. Moreover, fathers who are responsible for several of these tasks might be more family oriented and therefore influence their wives' desire for a second child.

In an analysis on the consequences of fathers' participation in family work, Baruch and Barnett (1986) showed that the participation of fathers in "feminine" home chores had only a limited influence on their role-strain (e.g. time and energy constraints, role conflicts) and well-being whereas their participation in childcare was a significant predictor of fathers' feeling more involved and competent as parents, and of wives evaluating their husbands more highly as fathers. Although they concentrated on role-strain and well-being, their results support our findings since they found significant effects of the fathers' participation in childcare, but only limited effects for household tasks.

Interestingly, women who are responsible of four out of four childcare duties more often wish to have a second child than the others. At first sight, these women seem to get little help from their husbands, and this should decrease their childbearing intentions. On the other hand, high involvement in childcare might also indicate a more traditional family orientation and thus a higher desire for more children. We therefore find evidence not only for paternal but also for maternal involvement in childrearing. This argumentation also holds for women with a low involvement in childrearing, since those who take on none, or only one or two, out of our four defined childcare duties, have a significantly reduced desire for a second child. Following our previous conclusions, these women may be less involved in childcare partly because they are less family oriented and therefore harbor lower intentions to have a second baby. These arguments also hold true for household tasks, although the effects are not significant. Moreover, women who feel that the distribution of childcare duties is very unjust have a higher desire for a second child. Again, this result might be an indicator for a positive correlation between family orientation and traditional values of women.

Our findings confirm the importance of distinguishing between household work (especially traditionally feminine chores) and child care tasks (Baruch and Barnett 1986). The majority of studies on this subject focus on household labor and neglected childcare (e.g. Holzer and Münz 1996). Childrearing and housework are two qualitatively different dimensions which should not be confounded and the omission of childcare is particularly problematic because it seems to be more than just an additional element of family work. 
The analysis presented here has demonstrated the usefulness of including gender aspects in an analytical framework. Naturally, the desire for children is a more complex process than the one represented by our explanatory model. Further aspects not included in our analysis are, among others, selection during the mating process, experiences with the first child, time available for reaching one's personal goals, limited leisure time, or financial constraints. All of these certainly also influence a woman's decision to continue childbearing after the first child (Gisser et al. 1995, Kytir et al. 2000). Moreover, a comparison with the partner's desire for another child as well as the effect of the partner's own childbearing intentions would be an interesting extension of our analysis (Thomson 1997).

\section{References}

Aldrich, J.H. and F.D. Nelson (1986): Linear probability, logit, and probit models. Sage University Paper Series on Quantitative Applications in the Social Sciences, 07-045. Beverly Hills and London: Sage Publications.

Baruch, G.K. and R.C. Barnett (1986): Consequences of fathers' participation in family work: Parents' role-strain and well-being. Journal of Personality and Social Psychology 51, pp. 983-992.

Becker, G. (1981): A treatise on the family. London: Harvard University Press.

Berk, S.F. (1985): The gender factory. New York: Plenum.

Blair, S.L. (1993): Employment, family, and perceptions of marital quality among husbands and wives. Journal of Family Issues 14(2), pp. 189-212.

Blair, S.L. and M.P. Johnson (1992): Wives' perceptions of the fairness of the division of household labor: The intersection of housework and ideology. Journal of Marriage and the Family 54, pp. 570-581.

Brines, J. (1994): Economic dependency, gender, and the division of labor at home. American Journal of Sociology 100(3), pp. 652-688.

Buber, I. (2002): The influence of the distribution of household and childrearing tasks between men and women on childbearing intentions in Austria, Max Planck Institute for Demographic Research, Working Paper WP-2002-004, Rostock.

Cunningham, M. (2001): Parental influences on the gendered division of housework. American Sociological Review 66, pp.184-203.

DeMaris, A. and M.A. Longmore (1996): Ideology, power, and equity: Testing competing explanations for the perception of fairness in household labor. Social Forces 74(3), pp. 1043-1071.

Dillaway, H. and C. Broman (2001): Race, class, and gender differences in marital satisfaction and divisions of household labor among dual-earner couples. A case for intersectional analysis. Journal of Family Issues 22(3), pp. 309-327.

Doblhammer, G., W. Lutz and C. Pfeiffer (1997): Tabellenband und Zusammenfassung erster Ergebnisse: Familien und Fertilitätssurvey (FFS) 1996. Österreichisches Institut für Familienforschung. Materialsammlung Heft 2. Vienna: Austrian Institute for Family Studies.

Ferree, M.M. (1990): Beyond separate spheres: Feminism and family research. Journal of Marriage and the Family 52, pp. 866-884.

Frauen-Volksbegehren (1997): 716 der Beilagen zu den Stenographischen Protokollen des Nationalrates XX. Gesetzgebungsperiode. Parlamentarische Materialien. Vienna.

Gisser, R., W. Holzer, R. Münz and E. Nebenführ (1995): Familie und Familienpolitik in Österreich. Wissen, Einstellungen, offene Wünsche, internationaler Vergleich. Bundesministerium für Jugend und Familie. Graz: Styria.

Glass, J. and T. Fujimoto (1994): Housework, paid work, and depression among husbands and wives. Journal of Health and Social Behavior 35, pp. 179-191. 
Greenstein, T.N. (1996): Gender ideology and perceptions of the fairness of the division of household labor: Effects on marital quality. Social Forces 74(3), pp. 1029-1042.

Hanika, A. (1996): Volkszählung 1991: Paritäts-Fruchtbarkeitstafeln. Statistische Nachrichten 6/ 1999, pp. 426-431.

Hartmann, H.I. (1981): The family as the locus of gender, class, and political struggle: The example of housework. Signs 6(3), pp. 366-394.

Hiller, D.V. (1984): Power dependence and division of family work. Sex Roles 10, pp. 1003-1019.

Hoem, J.M., A. Prskawetz and G. Neyer (1999): Third births in Austria: The effect of public policies, educational attainment, and labor-force attachment, Working Paper 1999-02, Max Planck Institute for Demographic Research, Rostock.

Holzer, W. and R. Münz (1996): Kinderwunsch in Österreich. Zeitschrift für Bevölkerungswissenschaft 21(1), pp. 69-102.

Jaggar, A.M. (1983): Feminist politics and human nature. Lanham: Rowman\&Littlefield.

Kytir, J., I. Buber, D. Bichlbauer and U. Forster (2000): Bevölkerung und Familie in Oberösterreich. Vienna: Forschungsbericht 19 des Instituts für Demographie der Österreichischen Akademie der Wissenschaften.

Lillard, L.A. and C.W.A. Panis (2000): aML mulitlevel mulitprocess statistical software, release 1.0. Los Angeles, California: EconWare.

Oláh, L.S. (2001a): Gendering fertility: Second births in Sweden and Hungary. In: L.S. Oláh (2001): Gendering family dynamics: The case of Sweden and Hungary. Stockholm University Demography Unit - Dissertation Series. I, pp.1-50.

Oláh, L.S. (2001b): Gender and family stability: Dissolution of the first parental union in Sweden and Hungary. Demographic Research [Online], available at http://www.demographicresearch.org/Volumes/Vol4/2.

Perry-Jenkins, M. and K. Folk (1994): Class, couples, and conflict: Effects of the division of labor on assessments of marriage in dual-earner families. Journal of Marriage and the Family 56, pp. $165-180$.

Presser, H.B. (1994): Employment schedules among dual-earner spouses and the division of household labor by gender. American Sociological Review 59, pp. 348-364.

Sanchez, L. (1994): Gender, labor allocations, and the psychology of entitlement within the home. Social Forces 73(2), pp. 533-553.

Shelton, B.A. and D. John (1996): The division of household labor. Annual Review of Sociology 22, pp. 299-322.

Tazi-Preve, I.M., J. Kytir, G. Lebhart and R. Münz (1999): Bevölkerung in Österreich. Demographische Trends, politische Rahmenbedingungen, entwicklungspolitische Aspekte. Vienna: Schriften des Instituts für Demographie der Österreichischen Akademie der Wissenschaften Band 12.

Thomson, E. (1997): Couple childbearing desires, intentions, and births. Demography 34(3), pp. 343-354.

Toulemon, L. and M. Mazuy (2001): Les naissances sont retardées mais la fécondité est stable. Population 56(4), pp. 611-644.

West, C. and D.H. Zimmerman (1987): Doing gender. Gender \& Society 1(2), pp. 125-151.

Wiedenhofer, B. (1995): Zeitverwendung: Arbeitsteilung von Ehepartnern mit Kindern unter 15 Jahren. Statistische Nachrichten 8/1995, pp. 601-608. 


\section{Tables and figures}

Table 1: Time allocation of couples, by women's employment status. Austrian couples with one or more children under the age of 15 years

\begin{tabular}{|c|c|c|c|c|c|c|c|c|}
\hline \multirow[t]{2}{*}{$\begin{array}{l}\text { Woman's employment } \\
\text { status : }\end{array}$} & \multicolumn{2}{|c|}{ Employed } & \multicolumn{2}{|c|}{$\begin{array}{l}\text { Full-time } \\
\text { employed }\end{array}$} & \multicolumn{2}{|c|}{$\begin{array}{l}\text { Part-time } \\
\text { employed }\end{array}$} & \multicolumn{2}{|c|}{ Not employed } \\
\hline & Man & Woman & Man & Woman & Man & Woman & Man & Woman \\
\hline Monday to Sunday & & & & & & & & \\
\hline Employment & 6.49 & 4.16 & 6.44 & 4.42 & 6.58 & 3.26 & 7.10 & 0.27 \\
\hline Household & 2.07 & 5.54 & 2.12 & 5.41 & 1.57 & 6.18 & 1.56 & 8.43 \\
\hline Leisure & 4.24 & 3.10 & 4.21 & 3.00 & 4.30 & 3.29 & 4.16 & 3.54 \\
\hline Sleeping and private affairs & 10.34 & 10.35 & 10.36 & 10.31 & 10.32 & 10.44 & 10.31 & 10.52 \\
\hline Education & 0.06 & 0.05 & 0.07 & 0.06 & 0.04 & 0.03 & 0.07 & 0.04 \\
\hline Employment and household & 8.56 & 10.10 & 8.56 & 10.23 & 8.15 & 9.44 & 9.06 & 9.10 \\
\hline Monday to Friday & & & & & & & & \\
\hline Employment & 8.45 & 5.19 & 8.45 & 5.51 & 8.47 & 4.23 & 9.04 & 0.29 \\
\hline Household & 1.35 & 5.58 & 1.40 & 5.43 & 1.28 & 6.26 & 1.27 & 9.26 \\
\hline Leisure & 3.31 & 2.30 & 3.29 & 2.20 & 3.34 & 2.47 & 3.23 & 3.22 \\
\hline Sleeping and private affairs & 10.01 & 10.06 & 9.58 & 9.57 & 10.06 & 10.23 & 10.02 & 10.38 \\
\hline Education & 0.07 & 0.06 & 0.08 & 0.09 & 0.05 & 0.03 & 0.06 & 0.03 \\
\hline Employment and household & 10.10 & 11.07 & 10.25 & 11.34 & 10.15 & 10.49 & 10.31 & 9.55 \\
\hline
\end{tabular}

Source: Austrian Microcensus 1992, Wiedenhofer (1995).

Remark 1: All men in the sample of couples were employed. The number of couples where the husband was unemployed was very small and therefore these couples were not included in the analysis of time-allocation of couples by Statistics Austria (Wiedenhofer 1995, p. 601).

Remark: Numbers are given as "hours. minutes".

Table 2: Distribution of household chores and childcare tasks and women's appraisal of the distribution of these tasks in the data set. Austrian women aged 20 to 54 years with one child, currently living in a union. Percentages.

\begin{tabular}{|c|c|c|c|c|}
\hline Number of household tasks performed primarily by & Woman & Man & Both & Others \\
\hline None & 4.1 & 88.7 & 42.0 & 92.0 \\
\hline One & 8.0 & 6.3 & 21.4 & 4.7 \\
\hline Two & 17.9 & 3.0 & 17.3 & 3.3 \\
\hline Three & 13.7 & 1.4 & 12.1 & \\
\hline Four & 20.6 & 0.5 & 4.4 & \\
\hline Five & 35.7 & 0.0 & 2.7 & \\
\hline Number of childcare tasks performed primarily by & Woman & Man & Both & Others \\
\hline None & 12.1 & 92.0 & 20.6 & 97.3 \\
\hline One & 19.0 & 7.1 & 37.1 & 2.7 \\
\hline Two & 23.4 & 0.8 & 20.6 & 0.0 \\
\hline Three & 30.2 & 0.0 & 13.7 & \\
\hline Four & 15.4 & 0.0 & 8.0 & \\
\hline Woman's evaluation of the distribution of tasks & household & childcare & & \\
\hline Very just & 33.0 & 38.2 & & \\
\hline Quite just & 32.7 & 32.1 & & \\
\hline More or less just & 22.8 & 23.6 & & \\
\hline Quite unjust & 8.2 & 4.1 & & \\
\hline Very unjust & 2.7 & 1.1 & & \\
\hline No answer & 0.5 & 0.8 & & \\
\hline
\end{tabular}

Source: Austrian FFS, own calculations. 
Table 3: Relative rates for the desire to have a second child, Austrian women with one child who were living with a partner at the time of the interview

\begin{tabular}{|c|c|c|}
\hline Desire for a second child & $\begin{array}{l}\text { Within the } \\
\text { next } \\
2 \text { years }\end{array}$ & $\begin{array}{c}\text { At an } \\
\text { undecided } \\
\text { point in time }\end{array}$ \\
\hline Constant & 0.62 & 0.66 \\
\hline \multicolumn{3}{|l|}{ Siblings } \\
\hline No sibling & 0.62 & $0.38 * *$ \\
\hline One sibling and more & 1 & 1 \\
\hline \multicolumn{3}{|l|}{ Religiousness } \\
\hline Very religious & 1.29 & 1.12 \\
\hline Rather religious & 1 & 1 \\
\hline (Rather) non-religious & 0.84 & $0.63 *$ \\
\hline \multicolumn{3}{|l|}{ Rural/urban environment } \\
\hline Under 10,000 inhabitants & 1 & 1 \\
\hline 10,000 inhabitants and more & 0.86 & 0.78 \\
\hline \multicolumn{3}{|l|}{ Combined marital status } \\
\hline No union at birth of first child, cohabiting at time of interview & 0.66 & 1.87 \\
\hline No union at birth of first child, married at time of interview & 1.01 & 2.18 \\
\hline Cohabiting at birth of first child, cohabiting at time of interview & 0.77 & 1.21 \\
\hline Cohabiting at birth of first child, married at time of interview & 1.60 & 1.78 \\
\hline Married at birth of first child (and still married at time of interview) & 1 & 1 \\
\hline \multicolumn{3}{|l|}{ Woman's age at time of interview } \\
\hline $20-24$ years & 1.36 & 1.30 \\
\hline 25-29 years & 1 & 1 \\
\hline 30-34 years & 0.81 & $0.56 * *$ \\
\hline $35-39$ years & $0.39 * *$ & $0.33 * * *$ \\
\hline \multicolumn{3}{|l|}{ Number of hours of employment } \\
\hline Less than 25 hours & 1.35 & 1.13 \\
\hline 25-34 hours & 1.12 & 1.39 \\
\hline 35 hours and more & 0.74 & $1.95 *$ \\
\hline Not employed at time of interview & 1 & 1 \\
\hline \multicolumn{3}{|l|}{ Partner's number of pre-union children } \\
\hline None & 1 & 1 \\
\hline One or two & 1.02 & 0.88 \\
\hline \multicolumn{3}{|l|}{ Age of first child at time of interview } \\
\hline Under 1 year & 1.36 & $3.43 * * *$ \\
\hline 1 year & 1.47 & $3.26^{* * *}$ \\
\hline 2 years & 1.05 & 1.55 \\
\hline 3-5 years & 1.09 & 1.31 \\
\hline $6-9$ years & 1 & 1 \\
\hline $10-14$ years & 0.83 & 0.95 \\
\hline \multicolumn{3}{|l|}{ Family attitudes } \\
\hline Very traditional & 0.97 & 1.74 \\
\hline Rather traditional & 1.31 & 1.14 \\
\hline Rather modern & 1 & 1 \\
\hline Very modern & 1.07 & 0.61 \\
\hline
\end{tabular}




\begin{tabular}{|c|c|c|}
\hline Desire for a second child & $\begin{array}{l}\text { Within the } \\
\text { next } \\
2 \text { years }\end{array}$ & $\begin{array}{l}\text { At an } \\
\text { undecided } \\
\text { point in time }\end{array}$ \\
\hline $\begin{array}{l}\text { Number of hh tasks performed primarily by the woman } \\
\text { One } \\
\text { Two } \\
\text { Three } \\
\text { Four } \\
\text { Five }\end{array}$ & $\begin{array}{r}0.57 \\
0.58 \\
0.68 \\
0.60 \\
1\end{array}$ & $\begin{array}{l}0.28 \\
0.45 \\
0.69 \\
0.44 * \\
1\end{array}$ \\
\hline $\begin{array}{l}\text { Number of hh tasks performed primarily by the man } \\
\text { None } \\
\text { One or more }\end{array}$ & $\begin{array}{r}1 \\
1.38\end{array}$ & $\begin{array}{c}1 \\
2.78^{* *}\end{array}$ \\
\hline $\begin{array}{l}\text { Number of hh tasks performed primarily by both } \\
\text { None } \\
\text { One } \\
\text { Two } \\
\text { Three } \\
\text { Four }\end{array}$ & $\begin{array}{r}1 \\
1.24 \\
1.28 \\
0.73 \\
2.92\end{array}$ & $\begin{array}{c}1 \\
2.29 * \\
1.76 \\
2.45 \\
2.84\end{array}$ \\
\hline $\begin{array}{l}\text { Woman's evaluation of the distribution to the hh tasks } \\
\text { Very just } \\
\text { Quite just } \\
\text { More or less just } \\
\text { Quite unjust } \\
\text { Very unjust }\end{array}$ & $\begin{array}{r}1.04 \\
1.53 \\
1 \\
1.26 \\
1.53\end{array}$ & $\begin{array}{r}1.62 * \\
1.47 \\
1 \\
1.97 \\
0.93\end{array}$ \\
\hline $\begin{array}{l}\text { Number of cc tasks performed primarily by the woman } \\
\text { None } \\
\text { One } \\
\text { Two } \\
\text { Three } \\
\text { Four }\end{array}$ & $\begin{array}{r}0.14^{* *} \\
0.31^{* *} \\
0.56 \\
1 \\
1.40\end{array}$ & $\begin{array}{l}0.22 * \\
0.33 * \\
0.54 * \\
1 \\
4.34 * *\end{array}$ \\
\hline $\begin{array}{l}\text { Number of cc tasks performed primarily by the man } \\
\text { None } \\
\text { One or more }\end{array}$ & $c^{1}{ }^{* 6 * *}$ & $\begin{array}{c}1 \\
2.97^{* *}\end{array}$ \\
\hline $\begin{array}{l}\text { Number of cc tasks performed primarily by both } \\
\text { None } \\
\text { One } \\
\text { Two } \\
\text { Three } \\
\text { Four }\end{array}$ & $\begin{array}{c}0.59 \\
1 \\
2.02 * \\
2.90 * \\
11.77 * * *\end{array}$ & $\begin{array}{c}0.32 * \\
1 \\
1.56 \\
2.90 * \\
34.80 * *\end{array}$ \\
\hline $\begin{array}{l}\text { Woman's evaluation of the distribution of cc tasks } \\
\text { Very just } \\
\text { Quite just } \\
\text { More or less just } \\
\text { Quite unjust } \\
\text { Very unjust }\end{array}$ & $\begin{array}{r}1.08 \\
0.84 \\
1 \\
1.70 \\
1.35\end{array}$ & $\begin{array}{r}1.45 \\
1.27 \\
1 \\
0.88 \\
1.80\end{array}$ \\
\hline In-L & -172.95 & -146.80 \\
\hline
\end{tabular}

Remark 1: Significance: $" * n=10 \%, " * * "=5 \%, " * * * "=1 \%$.

Remark 2: The effects are given as the antilog.

Remark 3: "hh" stands for "household", "cc" stands for "childcare".

Source: Austrian FFS, own calculations. 


\section{Appendix}

Many studies of family formation emphasize the importance of family characteristics and of early influences on family formation behavior later in life. Accordingly, we controlled for the effect of (1) the respondents' number of siblings, (2) their degree of religiousness, and (3) the rural or urban environment the respondents lived in during their childhood and adolescence. Moreover, we controlled for union-specific characteristics and other variables present at the time of the interview such as (4) the combined marital status (marital status at the birth of the first child and at the time of the interview), (5) the women's age at the time of the interview, (6) the women's number of working hours (at the time of the interview), (7) the partners' number of pre-union children, (8) the age of the first child at the time of the interview, and (9) family attitude towards the combination of motherhood and employment. ${ }^{5}$

Table 3 shows the effects of our control variables. Except for woman's age at the time of the interview, we found no persistent significant effect in our two models (desire for a second child within the next two years or at an undecided point in time). Nevertheless, the effects mostly confirm our expectations and are briefly described here.

Women who grew up without a sibling less often wish to have a second child. For selfreported religiosity we observe that a high degree of religiosity increases the desire for a second child in the near future whereas non-religiosity decreases it. Not surprisingly, a rural environment in which the respondents lived in during their childhood and adolescence has an increasing effect on further family plans.

The effect of the combined marital status (the status at the birth of the first child and at the time of interview) reveals an increased desire for a second child among women who were cohabiting with their partner at the birth of their first child and who married at a later stage in their life. Marriage after the birth of the first child might be an indicator for a high family orientation and a "sign" that the couple wants a second child. In general, the desire for a second child is higher in marriage than in cohabitation.

Our covariate combined marital status includes a group of women who were living with their partner at the time of the interview but did not do so at the birth of the first child. These women have a lower desire for a second child within the next two years; however, they have a rather high desire for a second child at a later point in time. Although the corresponding coefficients are not statistically significant, the effects are interesting because the current partner may be another than the first child's father. Our results indicate that the presence of a new partner reduces the wish to have a second child relatively soon but increases the wish for a second child at a later stage in life.

Women make consistent decisions about childbearing under biological and social constraints that make certain ages more desirable than others for childbearing. Our results on the woman's age at the time of the interview illustrate - confirming previous research - a decreasing desire for a child with increasing age. In particular women with one child who are 30 years old or more have significantly lower childbearing intentions than mothers in their twenties. Women who intend to have more than one child in general give birth to their second child rather soon after the birth of the first child (Toulemon and Mazuy 2001).

5 In the Austrian FFS each respondent was asked to give the preferred combination of parenthood and employment (normative expectations). We used this information in order to generate the respondent's family orientation. 
The older a woman, the larger the likelihood that she already had a second child and also the smaller the likelihood that she intends to have a second child. Therefore, with increasing age women in our sample represent more and more a selected group which might bias our estimated effects.

Our findings on mother's enrollment in paid work indicate that full-time employment decreases the desire for a second child within the next two years, but increases the wish for a second child at an undecided point in time. Mothers in full-time employment are the most employment-oriented of all women and might not wish to have a child in the very near future, but at a later stage in their life. Therefore, full-time employment of mothers should not be treated as coterminous with no further childbearing plans.

The family attitudes of women, measured by the normative expectations on the combination of parenthood and employment, have no significant effect on the desire for a second child. The higher coefficients for more traditional women might be interpreted as an expected result. Aside from the woman's age at the time of the interview, the age of her first child at time of interview is a significant predictor for further childbearing intentions. Not surprisingly, our findings illustrate that there is a decreasing desire for a second child with increasing age of the first child. We refer again to the selection process to which our sample might be submitted. The older the first child, the more women who intend to have a second child are likely to have carried out their childbearing intentions already. Therefore, the older the first child, the more selective women in our sample might be. 